\title{
Fraud Examination of the Enron Corp Company
}

\author{
Mahmoud Mofid Abdul Karim ${ }^{1}$
}

\begin{abstract}
This research paper takes into consideration the tools that are availed by Modified Altman, Chanos, Beneish, among others, to evaluate Enron Corp yearly 10k financial report as filed with SEC for the years beginning 1997 to 2001 mainly to identify the financial fraud that the company committed and how it could have been prevented before it escalated beyond control. The reported base its primary data source on the SEC Edgar Database, which has information on financial statements for all publicly listed companies. After successfully applying analytical tools such as Altman's Bankruptcy Predictor, Fraud Statement Index, and Analytical tools, this research paper concludes that the company's fraud could have been detected early on between the years 1999- 2000 period (Lucas \& Koerwer, 2004).
\end{abstract}

Keywords: Bankruptcy, Financial ratios, Fraud, Beneish model.

1 SMC University. Zug, Switzerland.

Article Info: Received: August 27, 2021. Revised: September 18, 2021.

Published online: September 22, 2021. 


\section{Introduction}

\subsection{Fraud at Enron Corporation}

Fraud among corporate entities can have significant repercussions on the company involved. On a wider scope, the public confidence in capital markets also declines. One of the cases that caught the public eye involved the Enron Company (Lucas \& Koerwer, 2004). In Satyam India or the US, a case of financial fraud in a corporate entity raises questions on the credibility of auditors, financial analysts, the regulators, the reporting process and the government to an extent. The fall of the Enron Company created doubt regarding the soundness of the financial reporting and accounting system. Enron Corporation was one of the highest-rated companies based on a Fortune rating. It was accorded the Most Innovative Company in America title within the period 1997 to 2001(Selanda \& Hasanah, 2020).

The company's primary products and services were related to electricity, natural gas, and communications to retail and wholesale customers through their network of affiliates and subsidiaries. The company's business operations were segmented into five divisions: wholesale services; transportation and distribution; broadband services, retail energy services, etc. The company had expanded its operations to several countries but mainly operated in Europe, Canada US, Australia, India, South America, and Japan. In 2000, their wholesale services accounted for about $93 \%$ of the company's total revenue; $3 \%$ of revenues were from broadband, $4 \%$ from distribution and transportation, while other services accounted for less than $1 \%$ of total company revenue (Hariri et al., 2017).

In the wake of its collapse, Enron Corporation's employees lost about $\$ 1.3$ billion invested in the company's 401(k) accounts while investors lost capital to the tune of $\$ 61$ billion. The company had fooled and misled most regulatory institutions including government regulators, auditors, private security analysts, criminal prosecutors and board of directors. The fraud mastermind was an external company known as Arthur Anderson, whose accountants helped Enron Corporation achieve fraud instead of advising the company against it. The following section explores more about the history of Enron Company and the strategies that they applied in deceiving unsuspecting investors around the globe.

\subsection{History of Enron Company}

During the Reagan administration in the 1980s, price control mechanisms were eliminated, giving pipeline companies and gas producers the ability to contract efficiently. As a result, the market becomes highly deregulated. Before this initiative by the Reagan administration, the Federal government played a crucial role in regulating the market. In 1985, InterNorth merged with Houston Natural Gas to form Enron. At the time, InterNorth Company was based in Nebraska. Thus, Enron Corporation was established, a natural gas company with about 37,500 miles of pipe (Akra \& Chaya, 2020).

The company took advantage of deregulation to manipulate earnings and stifling competition in the sector; thus, rationalizing the entire market. In 1987, the company 
played a significant role in exposing oil traders based in the New York office, who had diverted the company funds to their accounts for personal gain. Thus, the Enron Corporation executive manager bluffed the market by reducing the company loss from $\$ 1$ billion to $\$ 140$ million. The company had actively begun trading in Natural gas in 1989, becoming the leading natural gas merchant in the United Kingdom and North America.

In 1991, the US SEC advised the company to seek mark-to-market accounting approval, which was subsequently granted in 1992. The company got into a partnership with Maharashtra in India to build a power plant that would cost a total of $\$ 2.5$ billion. In 1996, the company entered into an agreement with Uzbekistan to explore some 11 gas fields in the region for $\$ 1.3$ billion. Based on this new deal, the government of Maharashtra and Enron renewed their contractual commitment to shift the construction costs and thus reduce electricity tariffs. In the same year, the company got into another deal where the Dabhol deal was announced. In 1996, the COO of the company at the time, Richard Kinder, left and subsequently was replaced by Jeff Skilling (Hariri et al., 2017).

In 1999, the CFO of the company did an experimental run on whether he could exploit the governing rules of California's deregulated energy market. In the same year, the Board of Directors exempted the company's CFO from organizing a private equity fund that was meant to raise capital for the company deals. In the same year, Merrill Lynch, a company in the US, released a placement memo for LJM2 (Akra \& Chaya, 2020). In the subsequent year, 2000, the company stock rose by $26 \%$, it recorded a new high of $\$ 67.25$ per stock. It led to the launch of a new strategy named "Death Star" in the California market. In the preceding months, a warning was issued by the California ISO due to low power reserves.

The Enron Corporation announced at the same time that its broadband branch had merged with Blockbuster supply video-on-demand. Thus, pushing the company's stock to an all high of $\$ 90.56$ and a market valuation of the company to $\$ 70$ billion. By 2000, November, the FERC investigation officers had pardoned Enron Corporation for any wrongdoing which the company had committed in California. The company had made a deliberate accounting error by financing a collapsing deal that had not brought any revenue at the close of the 2000 financial year (Rosoff, 2007).

In 2001, a company known as Belden West Coast made a considerable profit of about \$254 million in a month. It convinced some stock analysts that the performance of broadband could be significant. Thus, they raised the value of the company and cashed in on $\$ 53$ million shares and options. After Skilling became the company's CEO, the Enron Corporation transferred a component of EES business to wholesale: the move was made to conceal the losses the company had incurred in EES (Akra \& Chaya, 2020). The company then scheduled an impromptu analyst conference call to try and boost its stock. In mid-2001, FERC began price caps in various western states to control the California oil crisis.

Enron Corporation's CEO made a bullish speech that led to the laying off of about 300 employees. The company subsequently replaced its CEO, resulting in Lay 
taking over from Skilling (Hariri et al., 2017).

Jim Chanos predicted with complete certainty that the Enron corporation stock would decline, and subsequently, the 10-Q announced Enron's cash flow to be a negative of $\$ 1.3$ billion. Skilling, the former CEO, sold $\$ 15.5$ million worth of stock to help raise sales over $\$ 70$. In 2001, the company recorded a loss of $\$ 618$ million in the third quarter and declared a non-recurrent loss item that resulted of $\$ 1.01$ billion charge against its balance sheet, partly related to some structured finance operation within the company. Consequently, the company's CEO, Lay, announced a $\$ 1.2$ billion reduction in shareholders' equity (Rosoff, 2007). An external company, Arthur Anderson, helped destroy a ton of Enron Corporation's documents in a massive shredding activity performed in October 2001. The shredding activity was triggered by an announcement by SEC to investigate the company.

In the subsequent months, the company frustrated the investigation process. In November 2001, it filed documents with the SEC, where it had revised its five-year period financial statements to explain the $\$ 586$ million in losses. A company known as Dynegy accepted to buy out the company at about $\$ 9$ billion in cash and stock, given that Enron had previously announced a restructuring formula for the $\$ 690$ million obligations. The company's shares fell below $\$ 1$. Subsequently, Dynegy withdrew from the deal. In 2001 December, the company filed for Chapter 11 protection against bankruptcy. It was followed by a criminal investigation into the company deals in 2002 (Hariri et al., 2017).

\subsection{Enron's Financial Fraud Strategies}

The company engaged in buying natural gas from producers at very high and unreasonable discounts. They then sold the same gas to wholesale customers via the company's pipeline system. It elevated the company to a market leader in the US natural gas market, given that it could reach the majority of market players (Boddy, 2019). This strategy was especially effective due to market deregulation in the Reagan administration. However, after the imposition of regulations to promote competition in the sector, the company was unable to maintain its buy low and sell high strategy with stiffening competition leading to the shrinkage of its profit margin in 1993 (Rosoff, 2007). The company opted to diversify to improve its deteriorating profitability. It diversified into other sectors of the economy through investing billions of dollars in trying and replicating the success it had in natural gas. The management did not understand that the strategy that worked in the Natural gas sector could not work in other sectors. The pillars they had in the natural gas sector included a wealth of experience in the natural gas business. However, in different sectors, they had minimal experience or knowledge; thus, the company failed to generate revenues despite considerable investments in those sectors (Boddy, 2019).

Despite its general success in the energy sector, Enron suffered losses in some markets. The power plant built in India using billions in dollars failed to operate, thus leading to accumulated losses. The cost structure of the company had been 
completely paralyzed with no significant repairs or growth in employment. The company's financial position was impaired because of greed and poor management. Enron borrowed about $\$ 30$ billion to manage its costs without any particular damage to its reputation. However, this information was never revealed to the public. The investors in the company had no idea that the company was losing money fast and had no control over mounting losses (Selanda \& Hasanah, 2020).

The rest of this paper is structured as follows: section two introduces the tools used to detect fraud and how they were used and in section three describes analytical tools used in unearthing instances for investigation and detecting bankruptcy. Section four is the discussion of results and finally section five concludes.

\section{Data and Analysis}

The data that was used in the examination of this particular fraud case was obtained from several sources. The company's financial statements were identified using the US SEC Edgar database. The economic data includes balance sheet statement, cash flow statement and Income statement (Boddy, 2019). An analysis of the financial statements, financial fraud is evident in the event the numbers in the consolidated three financial statements are not properly related. Based on the appropriate guidelines by Beneish, Altman, etc., a determination of fraud would be established on whether or not the information from Enron's financial statements make sense or suggest cases of fraud and imminent bankruptcy. The fraud case analysis would also provide a clue as to the earliest period when the said fraud might have occurred. The tools which were used in this report to assess Enron Corporation Fraud are given below (Lucas \& Koerwer, 2004).

\subsection{Beneish Fraud Statement Index}

Professor Messod Beneish formulated the Beneish fraud statement analysis index. The model uses an M-Score, which is based on 8 financial ratios, to determine whether a company may have manipulated its prospective earnings. The variables involved in the analysis are obtained from the company's financial statement. The model recommends a threshold M-Score beyond which the analyst can conclude that the financial statements have been materially misstated. The M-score is mainly focused on company revenue manipulation (Lucas \& Koerwer, 2004). If the M-score is greater than -2.22 , it indicates that the company maneuvered with its revenue earnings. The following formula gives the M-score (Boddy, 2019):

$$
\begin{aligned}
& M=-4.84+0.92 \times D S R I+0.528 \times G M I+0.404 \times A Q I+0.892 \times \\
& S G I+0.115 \times D E P I-0.172 \times S G A I+4.679 \times T A T A-0.327 \times L V G
\end{aligned}
$$

Where:

$D S R I$ - refers to the Day's sales in the receivable index.

$G M I$ - refers to Gross margin index.

$A Q I$ - refers to asset quality index. 
$S G I$ - refers to sales growth index.

$D E P I$ - refers to depreciation index.

$S G A I$ - relates to sales and general and administrative index.

$L V G I$ - refers to leverage index.

TATA - refers to total accruals to total assets.

\section{$2.2 \quad$ M-Score Calculation for the Periods Between 1998 and 2001}

The indices were calculated using balance sheet and income statement items retrieved from Enron's financial statements. The formulae for the indices and their corresponding values for the 1997 to 2001 financial years are presented in Table 1 below.

Table 1: The Beneish Fraud Statement Index

\begin{tabular}{|c|c|c|c|c|c|c|}
\hline Index & Formulae & $\mathbf{2 0 0 1}$ & $\mathbf{2 0 0 0}$ & $\mathbf{1 9 9 9}$ & $\mathbf{1 9 9 8}$ & $\mathbf{1 9 9 7}$ \\
\hline $\begin{array}{c}\text { Days' sales in } \\
\text { receivable index }\end{array}$ & $\begin{array}{c}\text { [receivables current year/sales current year] } \\
\text { [receivables prior year/sales prior year] }\end{array}$ & 0.51 & 0.55 & 1.18 & 1.61 & 1.31 \\
\hline Gross margin index & $\begin{array}{c}\text { [(sales prior year minus cost of goods sold } \\
\text { prior year)/sales prior year] } \\
\text { [(sales current year minus cost of goods } \\
\text { sold current year)/sales current year] }\end{array}$ & 1.15 & 0.05 & 6.51 & 1.67 & 22.10 \\
\hline Asset quality index & $\begin{array}{c}\text { [Current assets + Property, plant and } \\
\text { equipment] Total assets }\end{array}$ & 0.90 & 0.85 & 0.33 & 0.37 & 0.41 \\
\hline Sales growth index & sales current year/sales prior year & 1.11 & 1.77 & 1.04 & 0.99 & 0.09 \\
\hline $\begin{array}{c}\text { Depreciation index } \\
\text { [Depreciation current year/Depreciation + } \\
\text { PPE current year]/[Depreciation prior } \\
\text { year/Depreciation + PPE previous year] }\end{array}$ & 0.92 & 3.65 & 1.28 & 1.02 & 0.55 \\
\hline $\begin{array}{c}\text { Sales and general } \\
\text { and administrative } \\
\text { expenses index } \\
\text { [sales, general and administrative expenses } \\
\text { current year/sales current year] } \\
\text { [sales, general and administrative costs prior } \\
\text { year/sales prior year] }\end{array}$ & 1.08 & 0.46 & 1.15 & 1.29 & \\
\hline $\begin{array}{c}\text { Leverage index } \\
\text { [Long term debt + Current liabilities } \\
\text { current year/Total assets current year] } \\
\text { [Long term debt + Current liabilities prior } \\
\text { year/Total assets prior year] }\end{array}$ & 0.83 & 0.98 & 0.91 & 1.02 & \\
\hline $\begin{array}{c}\text { Total accruals to } \\
\text { total assets }\end{array}$ & $\begin{array}{c}\text { [Change in working capital-change in } \\
\text { cash change in current tax } \\
\text { payable-depreciation and amortization] } \\
\text { Total Assets }\end{array}$ & -0.13 & -0.18 & -0.12 & -0.09 & -0.10 \\
\hline
\end{tabular}


Table 2: M-scores for period between 2001 and 1998

\begin{tabular}{|c|c|c|c|c|}
\hline Index & $\mathbf{2 0 0 1}$ & $\mathbf{2 0 0 0}$ & $\mathbf{1 9 9 9}$ & $\mathbf{1 9 9 8}$ \\
\hline DSRI & 0.51 & 0.55 & 1.18 & 1.61 \\
\hline GMI & 1.15 & 0.05 & 6.51 & 1.67 \\
\hline AQI & 0.90 & 0.85 & 0.33 & 0.37 \\
\hline SGI & 1.11 & 1.77 & 1.04 & 0.99 \\
\hline DEPI & 0.92 & 3.65 & 1.28 & 1.02 \\
\hline SGAI & 1.08 & 0.46 & 1.15 & 1.29 \\
\hline LVGI & -0.13 & -0.18 & -0.12 & -0.09 \\
\hline TATA & 0.83 & 0.98 & 0.91 & 1.02 \\
\hline M-SCORE & -3.36952 & -3.20741 & -0.16577 & -2.30371 \\
\hline
\end{tabular}

M-score calculation using the indices obtained in Table are summarized in Table 2 above. Except for 1999 when the M-Score was -0.16577 , the M score exceeded the threshold of -2.22 for every year between 1998 and 2001. This finding suggests that the company altered its earnings for all reporting periods other than 1999.

\section{Supplementary Analytic Tools}

\subsection{Day's Sales Receivables Index}

This analysis focus on the Day's sales Receivables Index, which results in a ratio of $1: 1$, thus exhibiting a steady relationship. If the account receivables increase in the percentage of sales, the situation would need in-depth analysis. The Gross Margin Index is also called into use where a ratio less than 1:1 would indicate that the company's operational efficiency was declining and may end up in fraudulent activities. The Asset Quality Ratio is also used primarily in monitoring the costs (Boddy, 2019). In the events, the ratio is more significant than 1:1, it would imply that the price is deferred or capitalized, thus calling for a critical examination of the situation. The Sales Growth Index gives an in-depth overview of the ratio between the current sales and the previous year's sales. Finally, the Total Accruals to Total Assets Ratio, a significant outcome, would suggest that a larger portion of the entity's working capital consisted of cash item, thus calling for an examination of the situation (Rosoff, 2007).

Based on the ratios analysis, the Days Receivable Index ratio dropped since the year 2000, requiring examination. The Growth Margin Index ratio declined with a considerable margin in 2000, indicating a need for investigation. The Sales Growth Index ratio recorded an increase from 1999, thus also calling for examination.

The total accruals to total assets ratio exhibited a negative result from 1997 to 2001, thus calling for an investigation of the company financial statements (Akra \& Chaya, 2020). 


\subsection{The Altman's Discriminant Function Algorithm}

This analysis utilizes the z-score to detect bankruptcy. A score that is lower than 1.8 would imply that default is likely to occur. The following formulae are used in the determination of the $\mathrm{Z}$ score.

Assets $Z=$ Overall Index of Corporate Health given by:

$$
Z=(1.2 \times X 1)+(1.4 \times X 2)+(3.3 \times X 3)+(0.6 \times X 4)+(1.0 \times X 5)
$$

Where:

$X_{1}=$ Working Capital/Total Assets,

$X_{2}=$ Retained Earnings/Total Assets,

$X_{3}=$ EBIT/Total Assets,

$X_{4}=$ Market Value of Equity/Book Value of Total Debt, and

$X_{5}=$ Net Sales/Total ("Beneish M-score model," 2013).

Table 3: Financial ratios results based on the Enron's financial statements using US SEC Edgar filings and Z-Score Calculation (1997-2001)

\begin{tabular}{|c|c|c|c|c|c|}
\hline Formula & $\mathbf{2 0 0 1}$ & $\mathbf{2 0 0 0}$ & $\mathbf{1 9 9 9}$ & $\mathbf{1 9 9 8}$ & $\mathbf{1 9 9 7}$ \\
\hline $\mathrm{X}_{1}=$ Working Capital/Total Assets & -0.0088 & 0.0067 & -0.0077 & -0.0067 & -0.0037 \\
\hline $\mathrm{X}_{2}=$ Retained Earnings/Total Assets & 0.4888 & 0.4335 & 0.0222 & 0.0055 & 0.0066 \\
\hline $\mathrm{X}_{3}=$ EBIT/Total Assets & 0.1971 & 0.2300 & 0.2423 & 0.0367 & 0.3370 \\
\hline $\begin{array}{c}\mathrm{X}_{4}=\text { Market Value of Equity/ } \\
\text { Book Value of Total Debt }\end{array}$ & 0.9266 & 0.8519 & 0.7635 & 0.7399 & 0.8889 \\
\hline $\mathrm{X}_{5}=$ Net Sales/Total Assets & 0.4847 & 0.4964 & 0.2523 & 0.2754 & 0.3638 \\
\hline Z-score & 2.3647 & 2.3814 & 1.5318 & 0.8400 & 2.0141 \\
\hline
\end{tabular}

A score lower than 1.8 means the entity is on the brink of bankruptcy. From Table 3, Enron had a z-score of 1.53 in 1999 and 0.84 in 1998, which means that the company showed early signs of bankruptcy.

\section{Discussion}

In the Altman's Z-score computation, all companies found to have a $\mathrm{z}$-score that is more significant than 2.99 would be classified as non-bankrupt, while companies with z-scores of less than 1.81 are expected to go bankrupt in no more than 2 years. The difference between 1.81 to 2.99 is commonly known as a grey zone referred to as a zone of ignorance because of the particular vulnerability to misclassification. The aggregate Z-score for Enron Corporation for the period 1997 to 2001 was 1.611, which is lower than the required 1.81. From the aggregate view point, the company could be classified as bankrupt as early as 1997. Looking at the Z-scores on a year-to-year basis, the score fell below 1.81 at the close of the $1998 \mathrm{FY}$ and the company was expected to go bankrupt before the end of 2000.

Enron filed for bankruptcy in December, 2001, one year later than predicted by the 
model. The company's bankruptcy could have been delayed by the alteration of financial statements, which was shown to begin as early as 1998 (Hariri et al., 2017). From the Beneish model, an M-score score greater than -2.22 would indicate that the company manipulated its financial statements to show positive earnings. In the case of Enron, the Beneish model suggests that the company's financial statements were altered from 1998, when its M-score was 2.426.

Based on the metrics developed by Beneish, there is a high probability that the company's financial statements were falsified to show that the company was performing well. However, the individual indices used in this analysis provide mixed results given that of the eight indices used, only SGI, AQI and LEVI suggested values greater than 1998, thus supporting the results of the M-score results ( $\mathrm{Li}, 2010)$. The difference in the $1997 \mathrm{M}$-score and Z-score be inexplicable. It may suggest that the manipulation of data in 1998 was to cover particularly for the company's financial problems in 1997.

The results of them-score are significant with studies of Banish, which indicate that the financial statement of the date was characteristically altered, thus leading to the early flagging of Enron in 1998.

\section{Conclusion}

Based on the results above, the paper concludes that, without any doubt, the fraud committed by Enron Corporation could be detected between the periods 1999 to 2000. The fraudulent activities of the company could be seen using the tools used above. The findings of this analysis have practical implications for auditors, SEC investigators and other regulatory entities. The misstatement of financial statements through aggressive revenue recognition and concealment of losses using offbalance sheet arrangements has the effect of obscuring the company's financial wellbeing. In Enron's case, Altman's Z-score was below the acceptable threshold in 1998 but had recovered in the years leading to the bankruptcy filing.

Enron's bankruptcy was delayed for two years while the company continued to lose employees' retirement savings and investors capital due to auditors' failure to recognize the discrepancies in the structure of earnings. The researcher recommends that auditors use the M-score to supplement other tools in the risk-assessment stage of auditing. If the M-score is beyond the threshold of -2.22 , the audit team would operate under the assumption of material misstatement and would perform a more exhaustive audit before rejecting this assumption. Extreme M-scores would inform the auditors' design of the audit, requiring the use of larger and more representative samples as well as higher quality substantive evidence of the integrity of various accounts. 


\section{References}

[1] Akra, R. M. and Chaya, J. K. (2020). undefined. International Journal of Business and Management, 15(10), 70. https://doi.org/10.5539/ijbm.v15n10p70.

[2] Boddy, C. R. (2019). Enron scandal. Encyclopedia of Business and Professional Ethics, 1-4. https://doi.org/10.1007/978-3-319-23514-1_2-2.

[3] Hariri, H., Pradana, A. W. and Widjajanti, S. L. (2017).

Predicting financial statements corporate fraud: Beneish M-score model. JEMA: Jurnal Ilmiah Bidang Akuntansi dan Manajemen, 14(02), 92. https://doi.org/10.31106/jema.v14i02.506.

[4] Li, Y. (2010). The case analysis of the scandal of Enron. International Journal of Business and Management, 5(10). https://doi.org/10.5539/ijbm.v5n10p37

[5] Lucas, N. and Koerwer, V. S. (2004). Featured interview Sherron Watkins, former vice president for corporate development of Enron.

Journal of Leadership \& Organizational Studies, 11(1), 38-47. https://doi.org/10.1177/107179190401100106.

[6] Rosoff, S. M. (2007). The role of the mass media in the Enron fraud. International Handbook of White-Collar and Corporate Crime, 513-522. https://doi.org/10.1007/978-0-387-34111-8_25.

[7] Selanda, C. A. and Hasanah, A. (2020). Analysis of corporate bankruptcy and financial statement fraud prediction using Altman models and Beneish models. Proceedings of the 2nd International Conference on Applied Economics and Social Science. https://doi.org/10.5220/0010354501540164.

[8] The Beneish M-score model. (2013). Using Analytics to Detect Possible Fraud: Tools and Techniques, 119-170. https://doi.org/10.1002/9781118715789.ch04. 